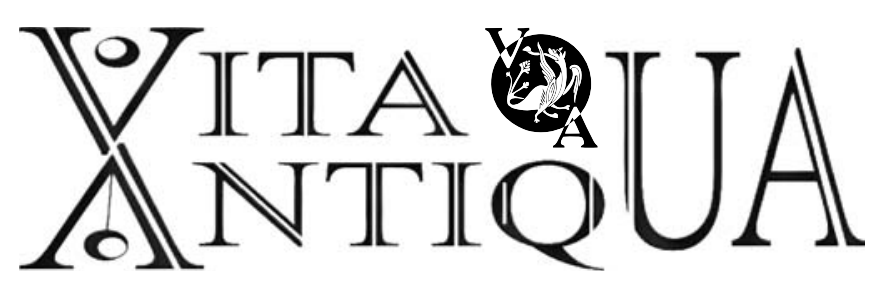

Vita Antiqua №10, 2018

TARAS SHEVCHENKO NATIONAL UNIVERSITY OF KYIV, FACULTY OF HISTORY DEPARTMENT OF ARCHAEOLOGY AND MUSEUM STUDIES

CENTRE FOR UNDERWATER ARCHAEOLOGY, ARCHAEOLOGICAL AND ETHNOLOGICAL RESEARCH

Th. VOVK CENTER FOR PALEOETHNOLOGICAL RESEARCH

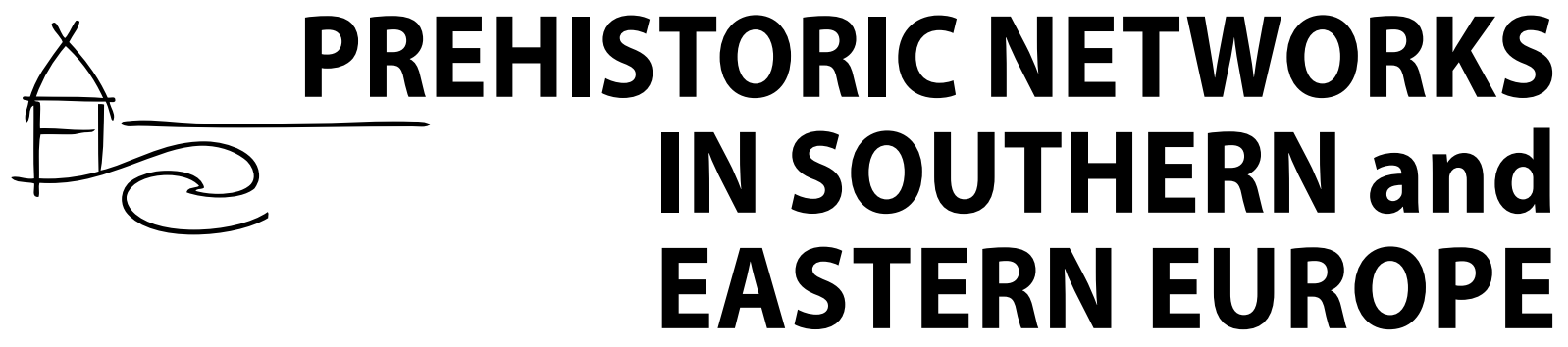




\section{FNSNF}

FONDS NATIONAL SUISSE

SCHWEIZERISCHER NATIONALFONDS

FONDO NAZIONALE SVIZZERO

SWISS National SCIENCE Foundation

Swiss National Science Foundation

Швейцарський Національний Науковий Фонд

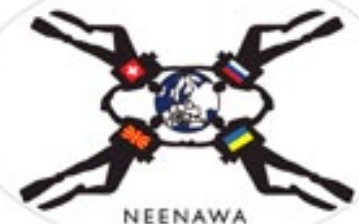

NEENAWA

SCOPES institutional partnership project Network in Eastern European Neolithic and Wetland Archaeology (NEENAWA)

SCOPES проект інституційного співробітництва "Мережа по дослідженню східноєвропейського неоліту та археології річок та озер"

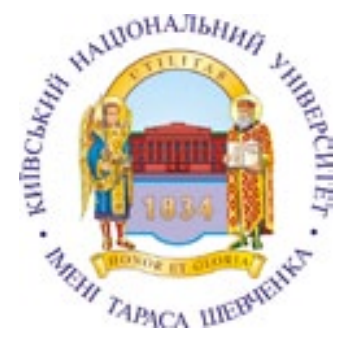

Faculty ofHistory, Taras Shevchenko National University of Kyiv

Історичний факультет Київського національного університету імені

Тараса Шевченка

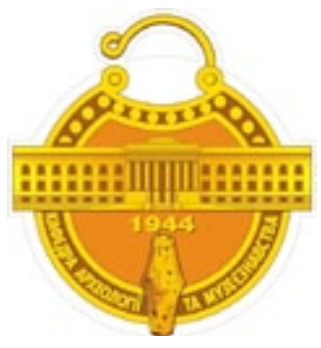

Department of Archaeology and Museology, Taras Shevchenko National University of Kyiv

Кафедраархеологіітамузеєзнавства

Київського національного університетуімені ТарасаШевченка

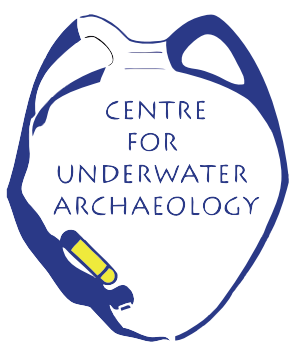

Centre for Underwater Archaeology, Archaeological and Ethnological Research

Центр підводної археології, археологічних та етнологічних досліджень

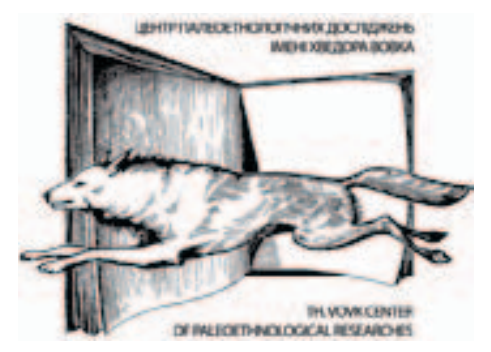

Th. Vovk Center for Paleoethnological Research, Ukraine

Центр палеоетнологічних досліджень ім. Хв. Вовка, Україна

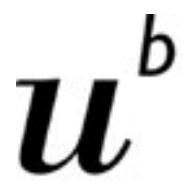

b

\section{UNIVERSITÅT}

BERN

University of Bern Бернський університет

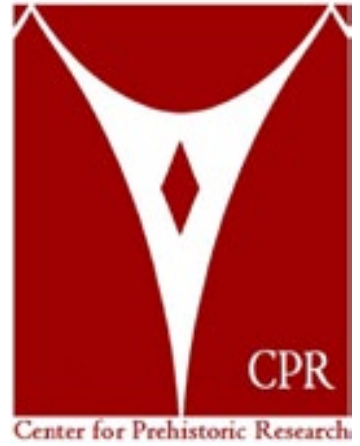

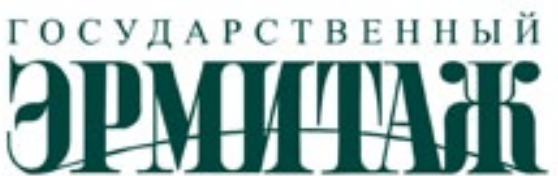

The State Hermitage Museum

State Hermitage Museum

Державний музей "Ермітаж”

Center for Prehistoric Research, Macedonia

Центр преісторичних досліджень, Македонія 


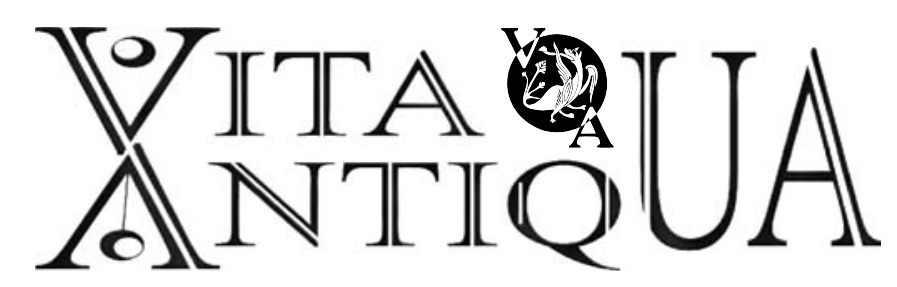

Vita Antiqua №10, 2018

КИЇВСЬКИЙ НАЦІОНАЛЬНИЙ УНІВЕРСИТЕТ ІМЕНІ ТАРАСА ШЕВЧЕНКА, ІСТОРИЧНИЙ ФАКУЛЬТЕТ КАФЕДРА АРХЕОЛОГІЇ ТА МУЗЕЄЗНАВСТВА

ЦЕНТР ПІДВОДНОЇ АРХЕОЛОГІЇ, АРХЕОЛОГІЧНИХ ТА ЕТНОЛОГІЧНИХ ДОСЛІДЖЕНЬ ЦЕНТР ПАЛЕОЕТНОЛОГІЧНИХ ДОСЛІДЖЕНЬ іМ. ХВ. ВОВКА

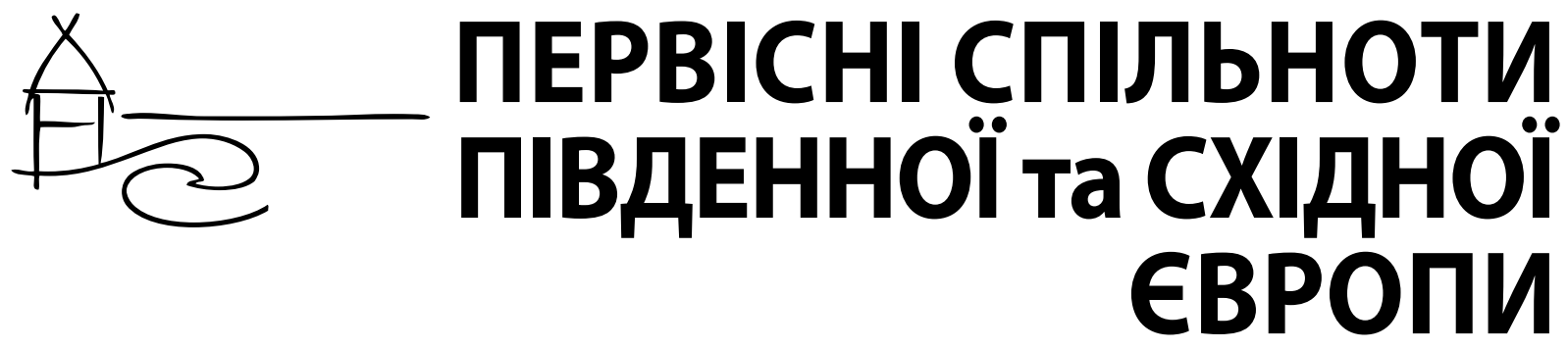




\section{VITA ANTIQUA № 10, 2018}

EDITORIAL BOARD:

Dr., Prof. Rostyslav V. Terpylovskyi, Taras Shevchenko National University of Kyiv, Ukraine (Head of the Editorial Board) Ph.D., assoc. prof. Pavlo S. Shydlovskyi, Taras Shevchenko National University of Kyiv, Ukraine (executive editor) Dr., Prof. Albert Hafner, University of Bern, Switzerland Dr., Prof. Mykhailo I. Hladkykh, Taras Shevchenko National University of Kyiv, Ukraine

Dr., Prof. Valerii P. Kapeliushnyi, Taras Shevchenko National University of Kyiv, Ukraine

Dr., assoc. prof. Henadii M. Kazakevych, Taras Shevchenko National University of Kyiv, Ukraine

HDR Marylène Patou-Mathis, Research director at CNRS, Muséum national d'histoire naturelle, France

Dr., assoc. prof. Stéphane Péan, Muséum national d'histoire naturelle, France

Ph.D., assoc. prof. Serhii M. Ryzhov, Taras Shevchenko National University of Kyiv, Ukraine

Dr., Prof. Viktor V. Stavniuk, Taras Shevchenko National University of Kyiv, Ukraine

Dr., Prof. Marzena Szmyt, Poznań Archaeological Museum, Poland

\section{EDITORIAL BOARD OF THE VOLUME:}

Pavlo S. Shydlovskyi, Taras Shevchenko National University of Kyiv, Ukraine (executive editor)

Aleksandr V. Diachenko, Institute of Archaeology NAS of Ukraine Ekaterina V. Dolbunova, State Hermitage Museum, Russian Federation Albert Hafner, University of Bern, Switzerland

Andrey N. Mazurkevich, State Hermitage Museum, Russian Federation Yana I. Morozova, Taras Shevchenko National University of Kyiv

Goce Naumov, Centre for Prehistoric Research, Republic of Macedonia Valentina Todorska, NU. Museum "d-r Nikola Nezlobinski", Republic of Macedonia

\section{TECHNICAL EDITORS:}

Yevhen Pichkur, Archaeological Museum, Institute of Archaeology NAS of Ukraine Ivan Radomskyi, Institute of Archaeology NAS of Ukraine

Denis Belousov, Taras Shevchenko National University of Kyiv, Ukraine

Martha Andriiovvych, University of Bern, Switzerland

Mariia Dobrotvor, University of Bamberg, Germany

\section{РЕДАКЦІЙНА КОЛЕГІЯ:}

Д.і.н., проф. Терпиловський Ростислав Всеволодович, Київський національний університет імені Тараса Шевченка (голова редакційної колегіі)

К.і.н., доц. Шидловський Павло Сергійович, Київський національний університет імені Тараса Шевченка (відповідальний редактор) Д-р, проф. Хафнер Альберт, Університет м. Берн, Швейцарія Д.і.н., проф. Гладких Михайло Іванович, Київський національний університет імені Тараса Шевченка

Д.і.н., проф. Капелюшний Валерій Петрович, Київський національний університет імені Тараса Шевченка

Д.і.н., доц. Казакевич Генадій Михайлович, Київський національний університет імені Тараса Шевченка

Д-р, досл. директор CNRS Пату-Матіс Марілен, Національний природничий музей, Франція

Д-р, доц. Пеан Стефон, Національний природничий музей, Франція

К.і.н., доц. Рижов Сергій Миколайович, Київський національний університет імені Тараса Шевченка

Д.і.н., проф. Ставнюк Віктор Володимирович, Київський

національний університет імені Тараса Шевченка

Д-р, проф. Шміт Мажена, Археологічний музей в м. Познань, Польща

\section{НАД ВИПУСКОМ ПРАЦЮВАЛИ:}

Шидловський Павло Сергійович, Київський національний університет імені Тараса Шевченка (відповідальний редактор)

Дяченко Олександр Вікторович, Інститут Археології НАН України

Долбунова Катерина Володимирівна, Державний Ермітаж, Росія

Хафнер Альберт, Університет м. Берн, Швейцарія

Мазуркевич Андрій Миколайович, Державний Ермітаж, Росія

Морозова Яна Іванівна, Київський національний університет імені Тараса

Шевченка

Наумов Гоче, Центр преісторичних досліджень, Македонія

Тодорська Валентина, Музей «д-р Нікола Незлобінський», Македонія

\section{ТЕХНІЧНІ РЕДАКТОРИ:}

Пічкур Євген, Археологічний музей Інституту археології НАН України Радомський Іван, Інститут Археології НАН України

Белоусов Денис, Київський національний університет імені Тараса Шевченка Андрійович Марта, Університет м. Берн, Швейцарія

Добротвор Марія, Університет м. Бамберг, Німеччина

Prehistoric Networks in Southern and Eastern Europe. Collection of scientific works. P. Shydlovskyi (ed.). VITA ANTIQUA, №10. - Kyiv: Center for Paleoethnological Research, 2018 - 212 p.

The collection of scientific works is devoted to contemporary research on development and interaction of prehistoric networks in the Holocene Europe. Chronologically, the collection covers the final phases of the Stone Age and the beginning of the age of early metals. Particular attention is paid to the process of Neolithization and interaction between different societies in Southern and Eastern Europe.

The proposed collection will be useful for anyone interested in the prehistory, archaeology and geography of Europe - archaeologists, prehistorians, specialists in local history, ethnographers, museum workers, cultural heritage researchers and students of higher educational institutions.

Первісні спільноти Південної та Східної Європи. Збірка наукових праць. П.С. Шидловський (відп. ред.). VITA ANTIQUA, №10. - К.: Центр палеоетнологічних досліджень, 2018. - 212 с.

Збірка наукових праць присвячена сучасним дослідженням питань розвитку та взаємодії первісних спільнот на території голоценової Європи. Хронологічно збірка охоплює заключні фази кам'яної доби та початку доби ранніх металів. Особлива увага приділена процесу неолітизації та взаємодії різних суспільств Південної та Східної Європи.

Запропонована збірка буде корисною для всіх, хто цікавиться первісною історією, археологією та географією Європи - археологам, преісторикам, історикам-краєзнавцям, етнографам, музейним працівникам, дослідникам культурної спадщини, студентам вищих навчальних закладів.

\section{Зареєстровано}

Міністерством юстиції України

Свідоитво про державну реєстрачію

КІ №1674 від 25.07.2017

Засновник та видавець

ГО Центр палеоетнологічних досліджень код ЄДРПУ №39633961

Україна, 02156, Київ, вул. Мілютенка, 15 а

E-mail: th.vovk.center@gmail.com

\section{Registered}

Ministry of Justice of Ukraine

Certificate of registration

KI №1674 вid 25.07.2017

Founder and publisher

Center for Paleoethnological Research

Unified State Register №39633961

Ukraine, 02156, Kyiv, str. Milyutenko, 15 a

E-mail: th.vovk.center@gmail.com
Підписано до друку 29.10.2018. Формат $60 \times 84 / 8$. Гарн. Myriad Pro. Папір офс. Друк офс. Ум.-друк. арк. 24,65. Тираж 300 екз.

Надруковано ФОП «Черенок К.В.» Свідоцтво В02 №353856 від 25.09.2006 p.

м. Київ, вул. Пушкінська, $45 / 2$ тел.: (044) 235-81-92, 228-45-05 


\section{CONTENTS / 3MICT}

FOREWORD: Network Approach for Studying the Prehistoric Networks (Pavlo Shydlovskyi, Yana Morozova) ПЕРЕДМОВА: Мережевий підхід у вивченні первісних спільнот (Павло Шидловський, Яна Морозова)

Dmytro Stupak. Chipped flint technologies of Janislawice culture in Ukrainian Polissya region

Дмитро Ступак. Технології розколювання кременю в комплексах яніславицької культури Українського Полісся

Sergii Telizhenko. The Køkkenmødding of Eastern Ukraine

Сергій Теліженко. Кьоккенмьоддінги Східної України

Alina Veiber. An overview of the osteological mammal material from the archaeological sites of the Surska culture in the context of its tribes' adaptation to the environment

Аліна Вейбер. Огляд остеологічного матеріалу ссавців з археологічних пам'яток сурської культури в контексті адаптації її носіїв до навколишнього середовища

Martha Andriiovvych. A sign of mobility and cultural exchange?The ceramics with scribblelineornamentation from Lysa Hora cemetery

Марта Андрійович. Ознака мобільності та культурного обміну? Керіміка з лінійним орнаментом 3 Лисогірського неолітичного могильника

Goce Naumov. The Formation of Wetland Identities in the Neolithic Balkans

Гоце Наумов. Формування заплавних ідентичностей у балканському неоліті

Pavlo Shydlovskyi. Lithic Assemblages of Early Agricultural Communities in Middle Dniester: comparative study

Павло Шидловський. Крем'яні комплекси ранніх землеробських спільнот Середнього Придністров'я: порівняльна характеристика

Ivan Radomskyi. Changing techniques of flint knapping in Chalcolithic times as an indicator of changes in the economy

Іван Радомський. Зміни у технології кременеобробки за доби енеоліту як показник змін у економіці

Yevhen Pichkur. Mining and distribution of flint by the tribes of Cucuteni-Trypillian community

Євген Пічкур. Видобуток і поширення кременю племенами Кукутені-Трипільської спільноти

Dmytro Zhelaha. Ornamentation systems of Trypillia culture B I period tableware in the Middle Dniester area Дмитро Желага. Орнаментальні схеми посуду Трипільської культури етапу В І в Середньому Подністров'ї

Aleksandr Diachenko. Geographic determinism and Trypillia contact networks, c. 3600 - 3400 BC

Олександр Дяченко. Географічний детермінізм та трипільські контактні мережі (3600 - 3400 BC)

Mykhailo Videiko, Nataliia Burdo. Life on the Eastern Frontiers of Old Europe

Михайло Відейко, Наталія Бурдо. Життя на східних рубежах Старої Європи

Robert Hofmann, Mila Shatilo, René OhIrau, Marta Dal Corso, Stefan Dreibrodt, Michailo Videiko, Knut Rassmann, Wiebke Kirleis, Johannes Müller. Tripolye - Strategy and Results of an ongoing Ukrainian-European Project

Роберт Хофманн, Міла Шатіло, Рене Олрау, Марта Даль Корсо, Стефан Драйбродт, Михайло Відейко, Кнут Рассманн, Вібке Кірлайс, Йоханес Мюллер. Трипілля - стратегія та результати поточного українсько-європейського проекту

Marzena Szmyt. Between the seas: Baltic-Pontic contact space in the $3^{\text {rd }}$ millennium BC

Мажена Шміт. Між морями: балтійсько-чорноморський контактний простір у 3-му тисячолітті до н.е.

Andrey Mazurkevich, Ekaterina Dolbunova, Luca Ottonello. Archaeological excavations and reconstructions of disappeared archaeological heritage (based on excavations in North-Western Russia)

Андрій Мазуркевич, Катерина Долбунова, Лука Оттонелло. Археологічні розкопки та реконструкції втраченої археологічної спадщини (на основі досліджень в Північно-Західній Росії)

Nikos Chausidis. 'River People' of the Northern Black Sea and Macedonia

Никос Чаусідіс. "Народи річок" Північного Причорномор'я та Македонії

STEP AHEAD: NEENAWA 2017 International Scientific Conference report (Yana Morozova, PavloShydlovskyi) КРОКВПЕРЕД:Міжнароднанаукова конференціяNEENAWA 2017,звіт(ЯнаМорозова,ПавлоШидловський) 


\title{
FOREWORD: Network Approach for Studying the Prehistoric Networks
}

\author{
Key words: network approach, prehistoric archaeology, Neolithic, Chalcolithic, neolithization, Eastern Europe
}

Dear friends and colleagues! Now you hold a new issue of the collection of scientific papers Vita Antiqua. This volume represents a part of the materials which were highlighted as the reports at the international scientific conference "Wetland Archaeology and Prehistoric Networks in Europe" that was held in Kyiv and Kaniv from the $15^{\text {th }}$ to the $18^{\text {th }}$ of September 2017 [Wetland... 2017]. This conference was the final event of the Institutional Partnership Programme (SCOPES) "Network in Eastern European Neolithic and Wetland Archaeology for the improvement of field techniques and dating methods (NEENAWA)", funded by the Swiss National Science Foundation (SNSF) [Hafner et al. 2015]. Here we are delighted to present some concluding remarks on its scope and achievements:

Transformations are taking place in Ukraine in all spheres of life, including science. We are settling down to a course of the innovation and development, increasing information streams and expanding areas of knowledge. All these challenges demand changes in approaches to Higher Education and training specialists-to-be, including researchers. Consequently, today as never before, this scientific and engineering progress and the rapid implementation of science into daily life demand from a young researcher not only good academic training but also practical skills.

The acquisition of knowledge, broadening of outlook and progression of creative thinking are achieved not only by means of generated curriculums and traditional instruction, but also by the active implementation of academic mobility for students and tutors throughout the educational process. For this foundation, a modern student must have the possibility not only take part in research activities in their home country, but also adopt experience and knowledge abroad, using instruments such as Institutional Partnership and Academic Mobility Programs. The NEENAWA Project is precisely this kind of instrument; it gave
Ukrainian students opportunities to visit the University of Bern in Switzerland and to take part in scientific workshops and training that were organized in the Countries-Participants of the Project [International... 2016; Prehistoric... 2016].

The participation of Ukrainian students in the training events organized through the NEENAWA project, is targeted at learning new research methods in order to apply them in Ukraine, for their own research projects as well as to set up new professional contacts with their European colleagues. In May 2017 the faculty's PhD students and teachers went on a study trip to Switzerland. From the $24^{\text {th }}$ to $27^{\text {th }}$ of May 2017 an education seminar "Neolithic Archaeology in Eastern Europe" was organized at the Institute of Archaeological Sciences of the University of Bern. Students and teachers from Macedonia, Ukraine and Switzerland took part in the seminar. Its purpose was to familiarize and interest the students of the University of Bern in the history of the primitive societies of the NeolithicChalcolithic period of Southeast Europe, which resulted in their reports.

Broadly, the NEENAWA project aims at fulfilling the following tasks which meet the goals and objectives of our University, helping to shape a young European researcher-archaeologist and elicit her/his potential. These objectives are to increase mobility, international socialization and scientific cooperation for students and faculty members; to involve Ukrainian students in NeolithicBronze Age Archaeology and Underwater Archaeology research; to increase the role of practical skills for archaeology students; to improve existing curricula through the creation of the new module "Wetland Archaeology"; to update and improve the laboratory research facilities of the Department of Archaeology and Museum Studies; and to facilitate access for Ukrainian researchers and students to European scientific information - digital resources.

Changes that occur in the modern world certainly influence the world of scientific thinking. 
Conversely, the scientific community creates modern approaches to these changes, and attempts to comprehend from a scientific point of view those global processes that are happening on the planet at the moment. The most significant transformations that we are able to place on record are the integration processes that became possible as a result of the dynamic development of the techno and info-spheres. The transformation of humankind into a single integrated system with universal and common properties is a consequence of this development.

The most pronounced integration processes arise in the fields of technology and science, because the rapid and productive exchange of innovative ideas allows the application of new approaches in various spheres of human life, and indeed is often the key to the quality of this life. Recently, there has been a qualitative leap in all human societies, connected with cardinal changes in the economic sphere, society, science and culture. Traditional hierarchical structures and elites are rapidly losing their monopoly on the means of production, information flow, and energy sources, while in the community, network connections are gaining more weight than administrative subordination. Modern society as an interaction of different-level networks becomes more characteristic in modern science. The concept of the network has become a brand of science, characterizing both the object of research and methodological approaches to the study of specific phenomena. In the modern world, when humanity, as never before feels the scale of global changes in the scientific and technological spheres, the search for examples of global transformations in mankind's past is of considerable interest.

Humankind is on the eve of significant changes both in the way of life-sustaining activity and in the ideological paradigm. Society naturally focuses its attention on similar transitional periods in History which mark a sharp break with previous traditions, are characterized by technological inventions and demonstrate discreteness in the historical continuity. That is why in contemporary anthropology and archaeology there is a significant revival in the studies of the initial stages of the anthroposociogenesis process, in the issues of the formation of the human mode of behavior and the emergence of the first civilizational structures in the anthroposphere. The study of these points of bifurcation, qualitative leaps in the development of nature and society is impossible without a system analysis of processes and phenomena, without the holistic and ecological approaches which characterizes modern science.

The process of Neolithization that in some regions of the Oecumene took the character of a "Neolithic revolution" was one of such global processes that influenced the development of all mankind. The Neolithic era should be considered as a significant increase in the capacity to conduct various forms of societies' life-sustaining activity as a result of the liberation from natural determinism in behavior after the fundamental changes in the natural environment at the end of the Pleistocene. If the formation of human society and culture took place in the conditions of the last Würm glaciation which stipulated strict dependence on the ways of husbandry of the environment, then a significant climate mitigation in the northern hemisphere, almost immediately led to development fanning out in all sectors of life. A vital point in the transformation of human culture, resulting in the formation of modern industrial relations and the active involvement of humanity in the transformational processes of the geosphere and biosphere of the planet is the transition to reproductive forms of economy. The "triggers" to the explosive changes in human life, however, were catastrophic events in the environment at the end of the last glacial period.

The Neolithic is an important archaeological period, belonging to the final stages of the Stone Age. It is a transitional epoch from the early and middle Stone Age - the Palaeolithic and Mesolithic with an exclusively appropriating form of obtaining means of subsistence compared to the era of early metals. In this period reproduction forms of farming got their widespread distribution, crafts began to be segregated and structurally complex societies formed. The process of Neolithization is understood as the spreading of innovations in the economic, technological and cultural spheres, among which the domestication of plants and animals play a prominent role. This process is also characterized by early forms of farming and cattle breeding, the hereto linked transition to relative sedentism of prehistoric collectives, the emergence of stationary housing construction, various stone and flint processing techniques, and the spread of pottery. A specificity of life activity was reflected in complex world-view ideas and perceptions, which were materialized in vivid art objects and ornamentations.

At this time the southern regions of Eastern Europe experienced a strong influence from the Near Eastern and Balkan centres of Neolithic culture. If in the Near East and the Balkans abrupt changes in the natural conditions quickly caused a reorientation to reproductive economy and related technological inventions, then on the vast plains of Eastern Europe, the process of Neolithization had a wave-like diffusion of innovations in a particular sequence.

The complexity of this process is evidenced by the various concepts and ideas offered by the researchers. The study of the Eastern European 
Neolithic is impossible without the involvement of data on the territory of Ukraine, since Ukraine occupies a large part of the European continent. Due to a number of famous scientists of the twentieth century it became possible to discover and study Ukrainian Neolithic sites. M.O. Makarenko, M.Ya. Rudinsky, V.M. Danilenko and D.Ya. Telegin should be mentioned among many others who laid the groundwork for the modern periodization scheme of the development of culture in the early Holocene and gave a volumetric analysis of the outstanding assemblages of the Neolithic period in Eastern Europe.

The development of technological approaches in the analysis of material cultural remains, along with the experimental and traceology methods for the interpretation of artefacts and their functions was a significant contribution to the understanding of Neolithization process in Eastern Europe. The comprehensive application of absolute and relative dating methods became a great impulse to create cultural and chronological schemes of the development of the Neolithic within the territory of Ukraine. Radiocarbon dating is still the most important method among others, both for archaeology and for the application of related disciplines such as paleobotany and zooarchaeology. Application of the geomagnetic survey methods allowed to understand the patterns of settlement strictures belonged to ancient farmers. The possibility of access to information from neighboring regions also has great value.

In recent years, a number of sites which belong to different agricultural communities of Neo-Chalcolithic times have been investigated in the south-western part of Ukraine and in Moldova. They all are located in the basins of the Bugh, Dniester and Prut Rivers and demonstrate different variants of economic and cultural development in a particular region. Neolithic settlements include Sakarovka in Moldova, Yosypivka I (Dniester region), Dobrianka I-III, Pugach and Gard (Southren Bugh region), etc. Important conclusions were drawn from the studies of Trypillya settlements of Taliyanky, Maidanets'ke, Bernashivka I, OzheveOstriv, etc. The peculiarity of studying these sites is the high methodological level of research, resulting in obtaining considerable series of various categories of material culture, including pottery, flint, bone and antler products. It makes possible to conduct a comparative analysis of the sites and to trace similar and distinctive features in the processing technology. Studying Neolithic sites using up-to-date techniques has largely shed light on the features of each specific cultural phenomenon and raised questions about the polivariant development of the Early Holocene communities, and about the necessity of taking into account environmental, economic, social, migration and ideological factors in the development of cultural complexes. Most of the modern research of Neo-Chalcolithic sites is the result of international cooperation between Ukrainian and European scientists.

Theodore Vovk (Volkov) (1847-1918), a Ukrainian scholar of anthropology and archaeology, deeply understood the importance of scientific integration. His work as an anthropologist and pre-historian linked the centres of Ukraine, the Balkans, Western Europe and Russia. Representing national archaeology in the academic societies in European countries, he established the school of paleoethnology on the territory of the former Russian Empire, initiating schools for the study of prehistory in St. Petersburg and Kiev. He understood the paleoethnological direction itself as a multidisciplinary approach to the study of the vestiges of the past. Even after a century, for understanding the global processes there is a need in comprehensive integrative research, which pool together efforts of scientists from across sub-disciplines.

The current state of Ukrainian archaeology should be described as an integration stage, which is characterized by the representation of the achievements of national science in the world on the one hand and the adaptation of world experience for a more complete coverage of past phenomena on the other hand. In the context of the crisis of traditional scientific institutions and outdated approaches, modern research increasingly acquires a networked character, that manifests itself in the cooperation of specialists from different scientific fields and institutions when investigating a specific scientific problem. The consequence of these changes, which one can see in our country during the last several years, is a process of cultural integration of Ukraine into the European space, which is maintained by varied programs of scientific and cultural cooperation. For the modern Ukrainian humanitarian sphere, we have issues which are connected with the unification of methodology, modernization of approaches and the inclusion of the scientific achievements of our country into European scientific heritage.

The Project "Network in Eastern European Neolithic and Wetland Archaeology for the Improvement of Field Methods and Dating Methods" (NEENAWA) of the SCOPES Institutional Partnership Program, funded by the Swiss Science Foundation, is the first step towards establishing ground for cooperation on the study of the Neolithic in Eastern Europe. The name of our conference "Wetland Archaeology and Prehistoric Networks in Europe" is symbolic within the framework of this project. 


\section{References:}

Hafner, A.; Nielsen, E.H.; Mazurkevich, A.; Dolbunova, E.; Naumov, G.; Morozova, Y.; Shidlovsky, P. (2015). NEENAWA: Network in Eastern European Neolithic and Wetland Archaeology: first steps. The European Archaeologist, 46 (Autumn 2015): 68-70. DOI: 0.7892/boris.73296.

International Scientific Conference «HUMAN \& LANDSCAPE: Geographical approach in the Prehistoric Archaeology» (February 3-5, 2016, Kyiv, Ukraine) : Abstracts. - Kyiv. - 94 p. DOI: 10.5281/zenodo.1188554.

Prehistoric Wetlands and Lakes: bringing forward dendrochronology in archaeology. NEENAWA Scientific Meeting (11-17.05.2016, Scopje and Ohrid, Republic of Macedonia), Scopje, 2016. - 50 p. DOI: $10.5281 /$ zenodo.1542927.

Wetland Archaeology and Prehistoric Networks in Europe / NEENAWA International Scientific Conference, September $15^{\text {th }}-18^{\text {th }}, 2017$ / eds. Y. Morozova, P. Shydlovskyi. Kyiv - Kaniv, 2017. - 78 p. DOI: $10.5281 /$ zenodo.1188273. 
Vita Antiqua,

№ 10, 2018, C. 6-12

Павло Шидловський, Яна Морозова

\section{ПЕРЕДМОВА: \\ Мережевий підхід у вивченні первісних спільнот}

Ключові слова: мережевий підхід, первісна археологія, неоліт, енеоліт, неолітизація, Східна Європа

Шановні друзі та колеги! Наразі ви тримаєте новий випуск збірки наукових праць Vita Antiqua. Ця збірка представляє частину матеріалів, які були оприлюднені в доповідях на міжнародній науковій конференції "Археологія річок та озер і первісна археологія Європи", яка проходила в Києві та Каневі з 15 по 18 вересня 2017 року (Wetland... 2017). Конференція стала заключною подією програми інституційного співробітництва SCOPES “Мережа по вивченню східноєвропейського неоліту та археології річок і озер" Проект NEENAWA, за підтримки Швейцарського національного наукового фонду (SNSF) [Hafner et al. 2015]. Ми раді представити читачам заключні висновки стосовно мети та досягнень цього проекту:

Перетворення відбуваються в Україні в усіх сферах життя, включаючи науку. Ми переходимо до курсу інновацій та розвитку, розширюємо інформаційні потоки та сферу знань. Всі ці виклики вимагають змін у підходах до вищої освіти та підготовки фахівців, включаючи майбутніх дослідників. Отже, сьогодні, як ніколи раніше, науково-технічний прогрес і швидке впровадження науки в повсякденне життя вимагають від молодого дослідника не тільки хорошої академічної підготовки, а й практичних навичок.

Набуття знань, розширення світогляду та розвиток творчого мислення досягаються не тільки за допомогою сформованих навчальних планів і традиційних курсів, а й шляхом активної реалізації академічної мобільності студентів і викладачів протягом всього навчального процесу. Для досягнення цього сучасний студент повинен мати можливість не тільки брати участь у науково-дослідній діяльності на батьківщині, але й засвоювати досвід та знання за кордоном, використовуючи такі інструменти, як інституційне партнерство та програми академічної мобільності. Проект NEENAWA - саме такий інструмент; він дав українським студентам можливість відвідати Бернський університет у Швейцарії та взяти участь у наукових семінарах та тренінгах, які були організовані в країнах-учасницях проекту [International... 2016; Prehistoric... 2016].

Участь українських студентів у навчальних заходах, організованих у рамках проекту NEENAWA, спрямована на вивчення нових методів дослідження з метою їх застосування в Україні, для власних дослідницьких проектів, а також для встановлення нових професійних контактів зі своїми європейськими колегами. У травні 2017 року аспіранти та викладачі факультету відвідали Швейцарію з навчальною метою. 324 по 27 травня 2017 року в Інституті археологічних наук Бернського університету був організований освітній семінар "Археологія неоліту у Східній Європі". У семінарі взяли участь студенти та викладачі з Македонії, України та Швейцарії. Його головною темою було ознайомлення студентів Бернського університету з історією нео-енеолітичних суспільств Південно-Східної Європи.

Загалом, мета проекту NEENAWA відповідає цілям і завданням нашого університету, допомагаючи формувати молодого європейського дослідника-археолога і виявляти його/ї̈ потенціал. Ці цілі спрямовані на підвищення мобільності, міжнародної соціалізації та наукової співпраці студентів та викладачів; залучення українських студентів до досліджень в галузі археології неоліту-бронзи та підводної археології; підвищення значення практичних навичок для студентівархеологів; удосконалення існуючих навчальних планів шляхом створення нового курсу «Процес неолітизації Європи»; оновлення та вдосконалення можливостей лабораторних досліджень кафедри археології та музеєзнавства; сприяння доступу українських дослідників та студентів до європейської наукової інформації - цифрових ресурсів.

Зміни, що відбуваються в сучасному світі безумовно відбиваються на способі наукового мислення. I навпаки, наукове співтовариство створює сучасні підходи до цих змін і намагаєть- 
ся зрозуміти з наукової точки зору ті глобальні процеси, які відбуваються на планеті на даний момент. Найбільш суттєвими перетвореннями, які можливо зафіксувати, $\epsilon$ інтеграційні процеси, які стали можливими внаслідок динамічного розвитку техно- та інфосфери. Перетворення людства в єдину цілісну систему з універсальними спільними властивостями $\epsilon$ наслідком такого розвитку.

Найбільш яскраво інтеграційні процеси проявляються у технологічній та науковій галузях, оскільки швидкий і продуктивний обмін інноваційними ідеями дозволяє застосовувати нові підходи в різних сферах життя людини, а часто $є$ ключем до якості цього життя. Останнім часом спостерігається якісний стрибок у всіх людських суспільствах, пов'язаний з кардинальними змінами в економіці , науці, культурі та суспільстві. Традиційні ієрархічні структури і еліти швидко втрачають свою монополію на засоби виробництва, інформаційні потоки і джерела енергії, тоді як в суспільстві мережеві зв'язки набирають більшу вагу, ніж адміністративне підпорядкування. Розуміння суспільства в якості взаємодії мереж різного рівня стає більш характерним для сучасної науки. Концепція "мережі" стала брендом науки, що означає як об'єкт дослідження, так і методологічні підходи до вивчення конкретних явищ. У сучасному світі, коли людство, як ніколи раніше, відчуває масштаб глобальних змін у науково-технологічній сфері, пошук прикладів глобальних перетворень в минулому викликає значний інтерес.

Людство стоїть напередодні значних змін як у способі життєдіяльності, так і в світоглядній парадигмі. Наукові дослідження фокусують свою увагу на подібних перехідних періодах в історії, які відзначаються різким розривом з попередніми традиціями, характеризуються технологічними винаходами і демонструють дискретність історичного процесу. Саме тому в сучасній антропології та археології спостерігається значне відродження зацікавленості в дослідженнях початкових етапів процесу антропосоціогенезу, у питаннях формування людського способу поведінки та виникнення перших цивілізаційних структур в антропосфері. Вивчення цих точок біфуркації, якісних стрибків у розвитку природи і суспільства, неможливе без системного аналізу процесів і явищ, без холістичного і екологічного підходів, що характеризують сучасну науку.

Одним 3 таких глобальних явищ, що вплинули на розвиток всього людства, був процес неолітизації, який у деяких регіонах ойкумени набув характеру “неолітичної революції". Неолітичну добу слід розглядати як значне розширення спроможності ведення різних форм життєдіяльності суспільства внаслідок звільнення від природного детермінізму в поведінці після фундаментальних змін середовища наприкінці плейстоцену. Якщо формування людського суспільства і культури відбувалося в умовах останнього вюрмського заледеніння, що зумовило жорстку залежність способів господарювання від навколишнього середовища, то наступне значне пом'якшення клімату в північній півкулі, майже відразу призвело до розгортання розвитку у всіх секторах життя. Важливим моментом у трансформації людської культури, що призвело до формування сучасних виробничих відносин і активного залучення людства до процесів трансформації геосфери і біосфери планети, $\epsilon$ перехід до репродуктивних форм економіки. Однак, "спусковим гачком" вибухових змін у житті людини були катастрофічні події в навколишньому середовищі наприкінці останнього льодовикового періоду.

Неоліт $є$ важливим археологічним періодом, що належить до заключних етапів кам'яного віку. Це перехідна епоха від раннього і середнього кам'яного віку - палеоліту і мезоліту - 3 виключно привласнюючими формами отримання засобів існування, до епохи ранніх металів. В останній період відтворювальні форми господарства отримали широке розповсюдження, почали відокремлюватися ремесла і формуватися структурно складні суспільства. Процес неолітизації розуміється як поширення інновацій в економічній, технологічній і культурній сферах, серед яких помітну роль відіграє доместикація рослин і тварин. Цей процес характеризується поширенням ранніх форм землеробства і скотарства, з ним пов'язаний перехід до відносної осілості первісних колективів, виникнення стаціонарного домобудівництва, винайденням нових способів обробки каменю і кременю, поширення кераміки. Специфіка життєдіяльності знайшла своє відображення в складних світоглядних ідеях і уявленнях, які матеріалізувалися в яскравих мистецьких об'єктах та орнаментах.

У цей час південні райони Східної Європи зазнали сильного впливу з боку близькосхідних та балканських центрів неолітичної культури. Якщо на Близькому Сході та на Балканах різкі зміни природних умов швидко викликали переорієнтацію на репродуктивну економіку і пов'язані з цим технологічні винаходи, то на величезних рівнинах Східної Європи процес неолітизації мав хвилеподібне поширення інновацій в певній послідовності.

Про складність цього процесу свідчать різні концепції та ідеї, запропоновані дослідниками. Дослідження східноєвропейського неоліту неможливе без залучення даних по території України, оскільки Україна займає значну частину європейського континенту. Завдяки праці низки відомих вчених XX століття була відкрита та досліджена значна кількість неолітичних пам'яток. 
Серед багатьох інших слід відзначити М.О. Макаренка, М.Я. Рудинського, В.М. Даниленка та Д.Я. Телегіна, які заклали основу сучасної схеми періодизації розвитку культури на початку голоцену і подали об'ємний аналіз визначних неолітичних комплексів Східної Європи.

Розробка технологічних підходів при аналізі решток матеріальної культури, поряд з експериментальними і трасологічними методами інтерпретації артефактів та їх функцій, стала вагомим внеском у розуміння процесу неолітизації Східної Європи. Всебічне застосування абсолютних і відносних методів датування стало потужним імпульсом для створення культурно-хронологіч них схем розвитку неоліту на території України. Радіовуглецеве датування залишається одним 3 найважливіших методів датування, як для археології, так і для таких суміжних дисциплін, як палеоботаніка і зооархеологія. Застосування геомагнітних методів обстеження дозволило зрозуміти закономірності структур поселень стародавніх землеробів. Велике значення має також можливість доступу до інформації з сусідніх регіонів.

Останніми роками в південно-західній частині України та в Молдові досліджено ряд пам'яток, що відносяться до різних спільностей нео-енеоліту. Вони розташовані в басейнах річок Південний Буг, Дністер і Прут і демонструють різні варіанти економічного і культурного розвитку певного регіону. До неолітичних поселень відносяться Сакарівка в Молдові, Йосипівка I (Придністров'я), Добрянка I-III, Пугач і Гард (Південне Побужжя) та ін. Важливі висновки були зроблені з досліджень трипільських поселень Таллянки , Майданецьке, Бернашівка І, Ожеве-Острів та ін. Особливістю вивчення цих пам'яток $\epsilon$ високий методологічний рівень досліджень, результатом чого стало отримання значних серій різних категорій матеріальної культури, у тому числі крем'яних артефактів, кераміки, виробів з кістки та рогу. Це дає можливість провести порівняльний аналіз комплексів згаданих та інших пам'яток і простежити подібні і відмінні риси в технології обробки матеріалів. Вивчення неолітичних пам'яток 3 використанням найсучасніших методів значною мірою проливає світло на особливості кожного конкретного культурного явища і піднімає питання про поліваріантний розвиток спільнот в ранньому голоцені і про необхідність врахування екологічних, економічних, соціальних, міграційних та світоглядних факторів в розвитку культурних комплексів. Більшість сучасних досліджень неоенеолітичних пам'яток $\epsilon$ результатом міжнародного співробітництва між українськими та європейськими вченими та інституціями.

Хведір Вовк (Волков) (1847-1918 рр.), український антрополог та археолог, глибоко розумів важливість наукової інтеграції. Його діяльність як антрополога і преісторика пов'язувала наукові центри України, Балкан, Західної Європи та Росії. Представляючи вітчизняну археологію в академічних товариствах європейських країн, він заснував палеоетнологічну школу на території колишньої Російської імперії, започаткувавши центри вивчення первісної історії в Петербурзі і Києві. Палеоетнологічний напрямок він розумів як мультидисциплінарний підхід до вивчення пам'яток минулого. Навіть через століття, для розуміння глобальних процесів в первісну добу все ще $\epsilon$ необхідність у комплексних інтегративних дослідженнях, які б об'єднували зусилля вчених-спеціалістів з різних субдисциплін.

Сучасний стан української археології має бути описаний як інтеграційний етап, який характеризується, з одного боку, презентацією досягнень вітчизняної науки у світі, а з іншого боку адаптацією світового досвіду для більш повного висвітлення явищ минулого. В умовах кризи традиційних наукових установ і застарілих підходів, сучасні дослідження все більше набувають мережевого характеру, що проявляється у співпраці фахівців різних наукових галузей та інститутів при дослідженні конкретної наукової проблематики. Наслідком цих змін, які можна побачити в нашій країні протягом останніх кількох років, є процес культурної інтеграції України в європейський простір, який підтримується різноманітними програмами наукового та культурного співробітництва. Для сучасної української гуманітарної сфери ми маємо запити, пов'язані 3 уніфікацією методології, модернізацією підходів та включенням наукових досягнень нашої країни до європейської наукової спадщини.

Проект "Мережа по вивченню східноєвропейського неоліту та археології річок і озер для вдосконалення польових методів і методів датування" (NEENAWA) програми інституційного партнерства SCOPES, за підтримки Швейцарського наукового фонду, $\epsilon$ першим кроком на шляху створення підстав для співпраці в дослідженні неоліту у Східній Європі. 